\title{
The Marketization of University - Cause, Effect, Suggestion
}

\author{
Jiang Fan \\ Institute of Educational Science \\ Zhejiang Normal University \\ Jinhua, China \\ 1017299081@qq.com
}

\author{
Sun Dan \\ College of Teacher Education \\ Zhejiang Normal University \\ Jinhua, China \\ cone.sun@yahoo.com
}

\begin{abstract}
Marketization of university is determined by universal factors in the market of higher education, which has its special background and has become an inevitable trend. Marketization of university has both positive and negative effects for the state, society, universities, teachers and students. Paper put forward some suggestions to avoid negative side and exert its positive side.
\end{abstract}

Keywords-Popularization of Higher Education; Marketization of university; Knowledge Economy

With the deepening understanding and rapid development of higher education popularization, the market is gradually becoming the basic idea for reforming higher education. Marketization of university marketing has becoming the basic trend of world development of higher education. What is the Marketization of University? The author holds the same view with Zeng Kunsheng that university is running under the market mechanisms and laws of market operation, reconstructing its management system, operation mechanism and control system; adjusting teaching and amending its relationship between colleges and other social organizations. This wills gradually becoming a behavior process and trend of reforming marketization of market operators [1].

\section{INEVITABLE REASONS FOR MARKETIZATION OF UNIVERSITY}

\section{A. Arrival of Popularization of Higher Education}

"Popularization of Higher Education" means more people could have an access to higher education, which requires a sufficient number of institutions to meet more demand for higher education. Why marketization of university is the inevitable reason for popularization of higher education?

Firstly, in the period of elite higher education, the school's main funding comes from the government; while during popularization of higher education, due to increased enrollment and number of schools, the government cannot provide adequate funds for these institutions. Thus universities need to find other ways to get funds, and the marketization can be beneficial for the financial development of universities.

Secondly, in the period of elite higher education, the government will provide jobs for college graduates, so the employment pressure for college student is small; they just learn what schools teach them. However, during the popularization of higher education, the state cannot provide jobs for all college students, graduates need to find work by themselves, and requirements for them are pretty high. Graduates want to adapt to the new job as soon as possible, which requires them to have solid theoretical knowledge and problem-solving skills. However, in the past and even now, there is an obvious gap between students' ability and social requirements. As time passes, students began to complain about the teaching of university, the community also began to complain about the quality of schools, the state also want to improve the quality of education in universities, which requires university to integrate social requirements into daily teaching.

Third, in the period of elite higher education, there are much less number of teachers and students, and management tasks is much easier; professor is the one who is mainly responsible for the management of the school. In the Popularization of higher education, due to increased number of students, administrative tasks become more and more complicated, we cannot relying solely on a professor at the University. The importance and complexity of management requirements is relatively high, and management is precisely the strengths of market, which also contributed to the university market.

\section{B. Arrival of Modern Market Economy Era}

Modern market economy era mentioned here refers to the era of the knowledge economy in the context of the market economy system. Why modern market economy is an inevitable reason in marketization of university?

On the first place, before the coming of knowledge economy era, the production process of goods is not complicated, which is mainly the "manual-based, mental supplement?" So the market demands for educated workers is not too high, it is enough for workers to received substantially certain degree of general education or special education. So before knowledge economy era, the market has a limited influence on higher education. Whereas in the era of knowledge economy, the production process of goods becoming more complex, which is mainly the "mental based, manual supplement?" So the market demands for educated workers gradually becoming higher. Workers not only need to accept basically ordinary education, but also to access to higher education. Due to the continuous improving requirement for the labor quality, more workers desire to receive higher education, higher education which means they could be beneficial to their future employment. When the purpose for 
workers to enter higher education is to competiveness of selfemployment, the university needs to set their goals, curricula, and teaching methods according to the actual needs of students. These goals based on needs of students are certainly affected by market. Based on these, we believe that market is bound to have an influence on higher education.

On the second place, in the era of knowledge economy, knowledge contributes a lot to the economy, so the whole community is becoming increasingly concerned about the knowledge. However, university is not the only place for the dissemination of knowledge, but also a place to create knowledge. In addition, under the call for social responsibility and 'strengthen state with knowledge', the university should be aware of translating their own products 'knowledge' into productivity, and then promoting the development of society. However, the process of production of knowledge requires a lot of manpower and material resources in the socialist market economy system, the principle of equivalent exchange in the market are also applicable to exchange university and society, which also contributed to the marketization of whole university.

\section{THE IMPACT OF MARKETIZATION OF HIGHER EDUCATION}

\section{A. Positive impact}

Marketization of university will have a positive influence on the idea of 'University Concept', 'University Orientation', 'University Autonomy', 'University Management' and 'University Funds'.

Firstly, the marketization of university has changed the concept of university. University should be close to the community and the market. Thus, training objectives and curriculum of university will initiatively combine with the market. Based on this, people graduated from university will be more in line with the needs of national construction and the market. Marketization of university will also have a huge impact on the stability of the country. Imagine most graduate students were unemployment, and then the country will be in chaos. In the competition between countries, universities improving comprehensive strength through cultivating talents and transporting them into market, and be responsible for one mission of the university, that is to serve the community. Training people in accordance with social requirements and focusing on the practicability of course, which improved students' employability and competitiveness to some extent?

Secondly, marketization of university makes a difference to the position of university. That is to say those universities should form their own characteristics and take their distinctive road of development. During the process of marketization, students also have more choice and the right to withdrawal. While college students know the importance of the University, so universities must form their own characteristics to provide high quality education to attract students. In the process of the universities develop their own characteristics, different colleges gradually formed divergent styles between each other, which reflect the trend of diversification of higher education, and to meet the needs of different countries and social talents. At the same time, students can choose their favorite schools and majors according to their preference, which has a great positive effect on the formation of student's personality.
Thirdly, marketization of university leads to the change of autonomy of universities, which is an increase in university autonomy. In terms of capital, marketization of university means that the control over university is weakened, so you can get more autonomy. The increasing of university autonomy means universities could gain a step close to academic freedom and speech freedom. For universities, academic freedom has left a huge role no matter for research or management of university. Any sensible management does not want other people to control university, because unity implemented by mandatory will pose a tremendous harm to academic freedom. If the freedom of speech is limited in the university, then the university will not be able to hire creative scientists and scholars without cumbersome review. This would endanger the most unique contribution from university communityexploration and discovery of new knowledge. Similarly, teachers and scholars cannot enjoy the speech freedom and writing freedom, which will have a tremendous negative impact on them because they have devoted all their life to create and elaborate new ideas.

Fourth, marketization of university has changed the management of university, i.e. efficient university management. Some serious problems exist in much university management, such as complexity of management procedures. Some universities even have unclear responsibility; pass the buck to each other between departments. At the process of marketization of university, the pursuit of efficiency in the market, so these problems can be solved. Moreover, efficient management also has a great impact on professors. Due to series of management routine, professors are subject to many restrictions, they need to fill out many forms, subject to various audits. Efficiency of administrative work directly leads to high speed of various application and review. Higher efficiency of management will make application and review faster; professors will have more time to focus on their academic fields. Likewise, students have their own problems, higher efficiency of management will enable students to solve problems faster, so they can focus on learning and improve the quality of learning.

Fifth, marketization of university has changed university funds. Increasing university funding is conducive to hire firstclass professors, to create special courses and to give aids to students in need. New York University was built in 1831, it is not until 1980 then it starts to won prestige. From the beginning of the 1980s, New York University started to become not only a real competitor with Columbia University, but also a "global" famous university. Why New York University was growing so fast? The reason is from the beginning of the 1980s, New York University quickly raised funds and these funds would be used to hire top professors. It shows how important it is to have enough capital, and marketization of universities may cause an increase in university funding [2].

As we all know, it requires a lot of money to start a course, especially some special courses, featured courses will help universities enjoy a rapid development, fame. Such as the Massachusetts Institute of Technology is known for its worldfamous Polytechnic; University of Pittsburgh, known around the world for its philosophy; the University of Southern 
California is known for its film and sports. For a country, forming a unique discipline will be beneficial for developing expertise in this area and improve the comprehensive national strength. As for professor, the featured subjects mean that you can study the most advanced knowledge in typical field.

At present, it is not easy for many universities to have funding support from government. In order to obtain more funds, universities often persuade alumni to give finance support, which take heavy proportion in university funds. In the Popularization of higher education, state found it hard to assist all universities, and thus open up more channels for fundraising. Alumni are a great asset for university. If these alumni can receive fund in school life, then it will be much easier for them to give a financial support in return. College needs a lot of money to help students, and the marketization of university can help them to get more funding.

\section{B. Negative impact}

As the market behavior criterion is the law of value and principle of equivalent exchange, so the relationship between universities and other social institutions, universities and students will be understood as a simple 'buyer-seller relationship'. Teachers clearly know the value of time and money for the student; students also know that they have the right to occupy a certain time and effort of teachers. If students believe it is not worth to spend their money, they will seek compensation in court, which cover the economic relationship between teachers and students as educator and the educated. Therefore, if we over emphasis or over-valued the imparting relationship between universities and students in knowledge transferring, it is much possible to ignore the educational functions of universities. Weaken or loss of educational function will undoubtedly make universities only in its name. Increased market behavior will also contribute to the tendency of running utilitarianism, which makes university with a strong utilitarian color. This utilitarian reflected in the curriculum and research activities [3].

Firstly, according to the survey in mid-1980, 75 percent of universities graduates who were not required to grant a bachelor's degree were holding the European history; 77 percent of the universities did not offer courses in American literature or American history, 82 percent of the universities did not offer Ancient Greek and Roman civilization history curriculum; since 1970, universities which took history as the major courses decreased by $62 \%$, universities which took modern languages as majors universities reduced by $50 \%$, universities which took philosophy as a major subject decreased by $41 \%$ [4].

Secondly, in order to pursue economic interests and realize the economic value of cash as soon as possible, universities will usually change the consist of various researches, weaken the proportion of basic research and exaggerate application research into an inappropriate ratio. As we all know, university should consider its responsibility for scientific and social development in pursuit of economy when training talent, opening up subject and conducting scientific research. Therefore, not only should the teaching and research in university consider the real interests, but should also focus on the long-term development. The misbehavior of marketization of university will lead to utilitarianism, which would make it much harder for university to open up a new future [5].

\section{SUGGESTIONS FOR MARKETIZATION OF UNIVERSITY}

Marketization of university has become a necessity in the market knowledge economy of higher education. In addition, the university market has both positive and negative effects. Therefore, it is believed that the most important thing is to explore some strategies which could help universities gain the most success. Based on this, paper comes up with some suggestions and countermeasures from the perspective of state, schools, professors and students.

\section{A. National Perspective}

Marketization of university is already a historical necessity and has a tremendous positive impact, so the state should actively promote marketization of university. But there are certain negative effects in this process. Therefore, the government should promote marketization of university while play its role in macro guidance and supervision. Government should play its role as macro-guidance at the process of marketization of university, be clear about the consequence of things and make sure what to do or what not to do, put forward some request from the macro aspects. After clearly knowing the demand for college, government should give a strict supervision on them, grant the outstanding universities with reward and punish the universities for poor performance, and then to regulate the marketization of university.

\section{B. School Perspective}

The process of marketization of university should adhere to two principles: first, the primary mission in college - achieve goals on the basis of cultivating talent and innovative knowledge; second, achieve goals in charge of the state and society. Three main functions for college are: cultivate talents, scientific research and social services. It is believed that "cultivate talent and knowledge innovation" is the primary mission for the university. The reason why we call university is because there are student in the campus. If universities forgotten their primary mission, then it is not a successful university. Based on above reason, during the process of marketization of university, we must adhere to primary principle. University should exaggerate the positive impact and bring benefits for students. Universities should further exert a positive impact and also overcome other factors to destroy 'ivory tower spirit'. Destruction of 'Ivory tower spirit' will damage the impression from marketization of university to schools, teachers and students. University must be restrained confront with temptation of interests. The university is a 'greedy' institution which has endless desires. Why universities have endless desire? Because the university is managed by the people, the essential characteristics of human being are 'greedy'. But if over chasing of commercial interests may lead to the opposite effect. The marketization of university should have their own principles, that are the primary mission of the University - cultivate talents.

Universities must be responsible for their own research during the process of marketization of university. Universities must ensure that its research will do no harm to human beings, society and the state. University is a social institution and 
should be responsible for society. If the results of university research were harmful, then the benefit from marketization of university is no worth to be mentioned. Thus the second principle is that the marketization of university should take country and society as their foundation.

Some universities are over market-oriented and over pursuit of commercial interests. They did not meet the first principle and the second principle, the price they have to pay is pretty huge. If university cannot abide by its primary principle then it is not a truly outstanding university. The declination of personnel quality will result in a reducing of social acceptance, and even a further decline in the number of students, whereas tuition is a huge source of college funding. In addition, the government to give financial grants to universities is mainly based on their contribution to society. Government will give more support when universities can better promote the development and growth of the society, and vice versa. Government funding is also an important source of university funding. The most important three parts for university funding are - government funding, tuition, market funding. When a college encounters a sharp decline of student number, fewer government grants will be obtained, and then the universities will be faced with a serious crisis. In this case, the reputation and the number of excellent professors will be declining. However, the whole society usually takes first-class professor and reputation as the main factor when they choose their own colleges. Based on these, it is believed that there are two main principles that we should adhere to during the process of marketization of university.

\section{Teacher's Perspective}

One of the reasons most of people against the marketization of university is that they are afraid of the teacher will be distract by the other factors and concentrate on other work. They may take the teaching work as a burden, but to take another job in companies as another way to obtain money. It is also believed that teachers should complete their own work and then do some part-time jobs. This is mainly because of relatively low income of teachers. And teacher's life pressure is relatively large. If teacher could complete their work, and they could do some part-time teachers to not only alleviate pressure, but also transferring knowledge to more people and contribute to society and realize their life values. However, if a university professor could not finish their own job, then it is not appropriate for them to have another job, which will bring an opposite effect. As a teacher, complete their work and pursuit of mind freedom is their top priority, they should never be induced by money.

\section{Students' Perspective}

One main debating reason against marketization of university is that people are afraid of the ignorance of 'cultivating talent' as a primary principle for colleges. Students are fundamental for school; the quality of students is key factors which will influence the culture of school, society and even state. But the nurture of students' quality is affected by many factors, which takes passion for learning, commitment and attitude as core factors. So students could benefit a lot from the marketization of university and they could fully devote to learning in return. If the quality of students continues to improve, it is believed that those sounds of opposition for marketization of university will be much smaller.

\section{REFERENCES}

[1] Zeng Kunsheng, "Marketization of University: Inevitable Choice of University in Knowledge Economy Era," China Soft Science Magazine, 2001.

[2] David Kober, "Bottom line for Marketization of University," Peking University Press, 2008.

[3][5] Burton R.Clark, "Perspectives on Higher Education", University of California Press, 2001.

[4] Chen Lie, "Market Economy and Higher Education," People's Education Press, 1996. 